TITLE:

\title{
A NEW PEDUNCULATE CIRRIPED ON SPINES OF THE SEA-URCHIN, COELOPLEURUS MACULATUS
}

\author{
$\operatorname{AUTHOR}(\mathrm{S})$ :
}

Utinomi, Huzio

\section{CITATION:}

Utinomi, Huzio. A NEW PEDUNCULATE CIRRIPED ON SPINES OF THE SEA-URCHIN, COELOPLEURUS MACULATUS. PUBLICATIONS OF THE SETO MARINE BIOLOGICAL LABORATORY 1980, 25(1-4): 115-118

\section{ISSUE DATE:}

1980-02-29

URL:

http://hdl.handle.net/2433/175990

RIGHT: 


\title{
A NEW PEDUNCULATE GIRRIPED ON SPINES OF THE SEA-URGHIN, COELOPLEURUS MACULATUS ${ }^{1 \text { ) }}$
}

\author{
THE LATE HUZIO UTINOMI \\ 2565-27, Chuoh-dai, Shirahama-cho, Wakayama-ken, 649-22, Japan
}

With Text-figures $1-2$

Recently, on April 24, 1977, Mr. Hidetomo Tanase of the Seto Marine Biological Laboratory Aquarium at Shirahama obtained a number of beautiful pedunculate cirripeds. They were growing over the distal ends of large spines of a rare sea-urchin, Coelopleurus maculatus A. Agassiz et H. L. Clark, that had been fished with gill nets for spiny lobsters off Sakai of Minabe at the depths of 10-30 meters. He took excellent photographs in color of the live specimens of the cirripeds and provided me with them together with all fresh specimens. On looking at them, I was immediately convinced that they belonged to a new species of the genus Paralepas Pilsbry 1907. The descriptions of this new species are given below.

\section{Paralepas maculata, n. sp.}

(Japanese name: Azumauni-hadakaeboshi)

(Figs. $1 \& 2$ )

The material examined consists of 20 individuals. The largest one is selected as the holotype, SMBL-Type 290a, and other five smaller young ones as the paratype, SMBL-Type 290b-d, all deposited at the Seto Marine Biological Laboratory.

The animal is small-sized, ranging 5 to $10 \mathrm{~mm}$ in total length. The capitulum is globular in form, thick, hard and covered by a transparent integument studded with many short flexible prominences on the surface, and when alive, marked with a few red patterns on the carinal size which are adapted to the coloration of the spines of the host sea-urchin. These red patterns, however, fade away in alcohol, although the host's color patterns persist for a long time.

The stalk is slightly s-orter than the capitulum, cylindrical, hard and slightly constricted at the boundary between the capitulum and the stalk. The orifice lying near the apex on the occludent margin is small slit-like, not protruding. The scuta are quite absent.

Details of the cirri and mouth-parts are all typical of the genus Paralepas Pilsbry (1907), belonging to the family Heteralepadidae Nilsson-Cantell (1921). The caudal appendage is uniformly slender, 10-segmented and about twice as long as the proto-

1) Contributions from the Seto Marine Biological Laboratory, No. 653.

Publ. Seto Mar. Biol. Lab., XXV(1/4), 115-118, $1980 . \quad$ (Article 8) 


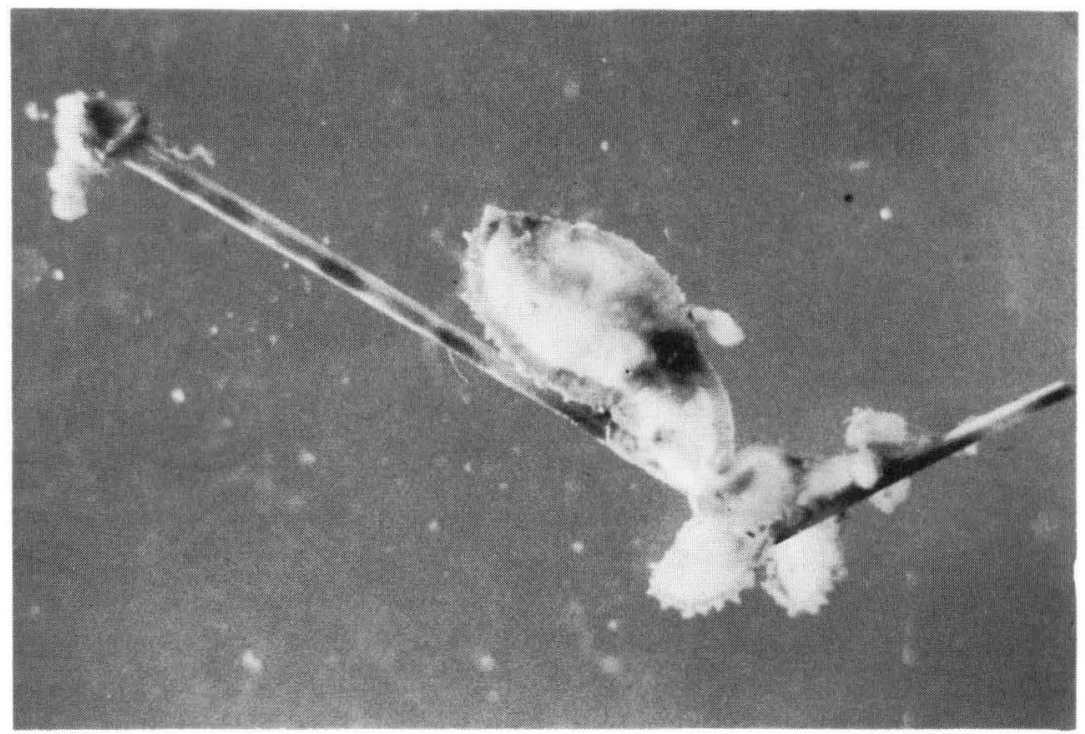

Fig. 1. Paralepas maculata, n. sp., on a spine of Coelopleurus maculatus as life habitat. Photo by courtesy of Mr. H. Tanase. The lower largest individual on the spine is selected as the holotype and the remaining smaller ones as the paratypes. Note the similar color patterns between the cirriped and the host sea-urchin's spine. Approximately $\times 3$.
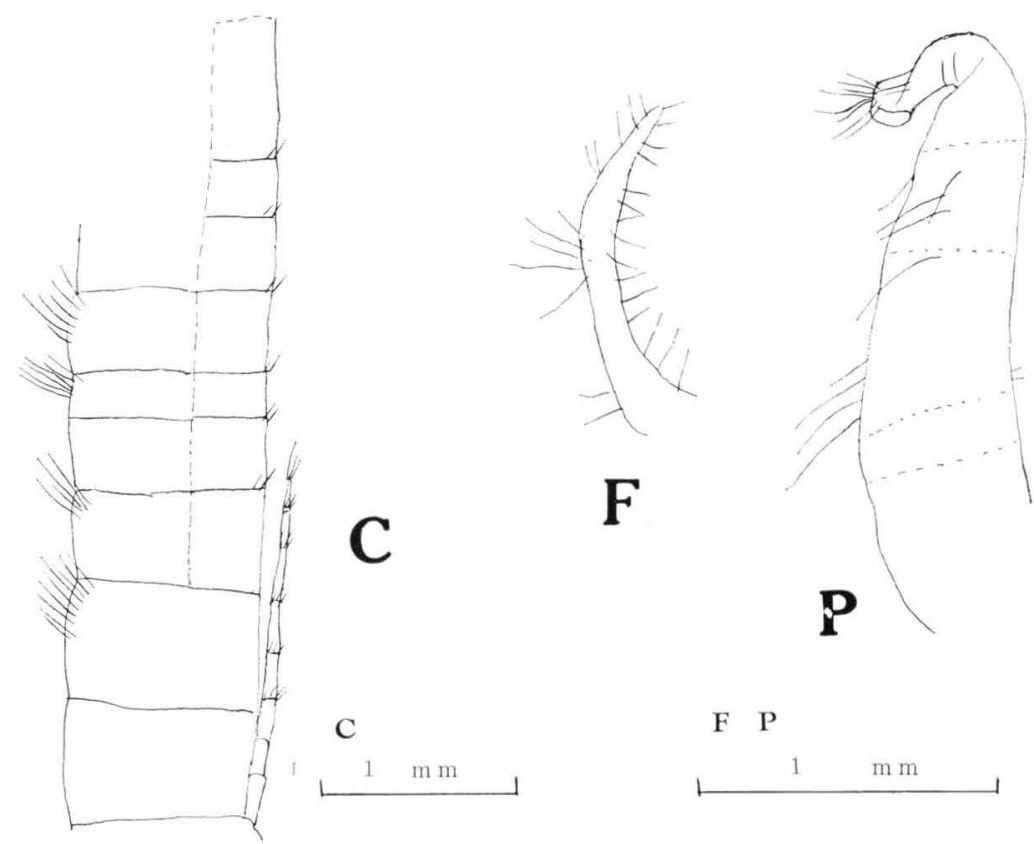

F P

Fig. 2. Lower part of the 6 th cirrus with the caudal appendage (C), terminal part of the penis $(\mathrm{P})$, and filamentary appendage $(\mathrm{F})$. 
podite of the last cirri (Fig. 2, c). The filamentary appendage is elongate and hairy. In contrast with the caudal appendage, the terminal cirri are generally short, plump, for the most part, hairy.

The penis is small, a little shorter than half of the last cirri, hairy and terminates to a short extremity (Fig. 2, P). The annulation seems to be indistinct, and rivet-like structures are apparently lacking. All these characteristics are quite unique, distinct from the other known species of Paralepas.

\section{Appendix: List of Known Species of Paralepas in Japan}

\section{Paralepas minuta nipponica Utinomi}

Japanese name: Uni-hadakaeboshi

Mostly attached to spines of Cidarid sea-urchins; Range: Wakasa Bay, Echizen Misaki, Toyama Bay, North of Sado Island, Tsuruga Straits (cf. Hiro, 1933; Hiro, 1937; Utinomi, 1970).

2. Paralepas xenophorae (Annundale)

Japanese name: Kumasaka-hadakaeboshi

Mostly attached to Xenophora and other deep-water living shells (cf. Hiro, 1937; Utinomi 1938).

3. Paralepas globosa (Hiro)

Japanese name: Daruma-hadakaeboshi

Mostly attached to deep-water living shells (cf. Hiro, 1936; Hiro, 1937).

4. Paralepas tuberosa (Nilsson-Cantell)

Japanese name: Ibo-hadakaeboshi

Only known from Sagami Bay (cf. Nilsson-Cantell, 1932; Hiro, 1937).

5. Paralepas rosea (Hiro)

Japanese name: Beni-hadakaeboshi

Attached to Macrocheira kaempferi (de Haan); Range: Sagami Bay to Kii coasts (NilssonCantell, 1921 as P. pedunculata; Krüger, 1911 as P. pedunculata; Hiro, 1937; Hiro, 1938).

6. Paralepas scyllarusi Utinomi

Japanese name: Himesemiebi-hadakaeboshi

Attached to uropods of Scyllarus bicuspidatus; Range: only known from Kamae Bay, Oitaken (cf. Utinomi, 1967).

7. Paralepas distincta (Utinomi)

Japanese name: Hoozukihadaka-eboshi

Generally attached to maxillipeds of Panulirus japonicus or legs of Maja spinigera; Range: Tomioka, Nomo-saki, or the western coast of Kyusyu (cf. Utinomi, 1949; Utinomi, 1962).

\section{Acknowledgements}

I am sincerely indebted to Mr. H. Tanase for collecting this new interesting Para- 
lepas species. My thanks are also due to Dr. M. Imafuku for the trouble of typing of the manuscript.

\section{REFERENGES}

Broch, Hj. 1922. Studies on Pacific Cirripeds (Papers from Dr. Th. Mortensen's Pacific Expedition 1914-16, X). Vidensk. Medd. fra Dansk naturh. Foren. 73: 215-358, 559-560.

1931. Indomalayan
LI). Ibid., $91: 1-142$.

Darwin, Ch. 1851. A monograph on the sub-class Cirripedia. The Lepadidae; or Pedunculated Cirripeds. Royal Society, London. xii $+400 \mathrm{pp} .10 \mathrm{pls}$.

Hiro, F. 1936. Descriptions of three new species of Cirripedia from Japan. Bull. Biogeogr. Soc. Japan, $6(23): 221-230$.

1937a. Studies on Cirripedian fauna of Japan. II. Cirripeds found in the vicinity of the Seto Marine Biological Laboratory. Mem. Coll. Sci. Kyoto Imp. Univ. Ser. B, XII(3): 385-478.

1937b. Thoracica, I (Pedunculate Cirripedia). Sanseido, Tokyo.

1938a. Report on the Cirripedia collected by the surveying ships of the Imperial Fisheries Experiment Station on the continental shelf bordering Japan. Rec. Oceanogr. Wks. Japan, V(1): 11-84, pls. I-III.

1938b. Notes on the animals found on Macrocheira kaempferi de Haan. I. Cirripeds, II. Molluscs. Annot. Zool. Japan., 17(3/4): 465-476.

- 1939. Studies on the Cirripedian fauna of Japan. III. Supplementary notes on the cirripeds found in the vicinity of Seto. Mem. Coll. Sci., Kyoto Imp. Univ. Ser. B, 15(2): 237-244.

Krüger, P. 1911. Beiträge zur Cirripedienfauna Ostasiens. Abh. Math.-phys. Kl. Bayer. Acad. Wiss. II Suppl.-Bd. 6 Abhandl.: 1-72, pls. I-IV.

Nilsson-Cantell, C.-A. 1921. Cirripedien-Studien. Zur Kenntnis der Biologie, Anatomie und Systematik dieser Gruppe. Zool. Bidrag. Uppsala, 7: 75-390, 391-392, pls. I*-III*.

Pilsbry, H. A. 1907. The barnacles (Cirripedia) contained in the collections of the U.S. National Museum. U.S. Nat. Mus. Bull., 60: i-x, 1-122, pls. I-XI.

1932. Cirripedien aus Japan, gesammelt von Dr. Smith, Dr. Haberer und Dr. Hilgendorf, in dem Berliner Museum aufbewahrt. Ark. Zool., 24A(4): 1-30, pl. I.

Utinomi, H. 1949. Studies on the Cirripedian fauna of Japan. VI. Cirripeds from Kyusyu and Ryukyu Islands. Publ. Seto Mar. Biol. Lab., I(2): 19-37.

- 1962. Studies on the Cirripedian fauna of Japan. VIII. Thoracic cirripeds from western Kyusyu. Ibid., (2): 211-239.

1967. Occurrence of a new pedunculate cirriped on a small spanish lobster Scyllarus bicuspidatus (de Haan) from Kamae Bay, northeastern Kyusyu. Ibid., XV(2) : 117-120.

1970. Studies on the Cirripedian fauna of Japan. IX. Distributional survey of thoracic cirripeds in the southeastern part of the Japan Sea. Ibid., XVII (5) : 339-372, pl. XVIII. 